\title{
Effect of Products and Images on Customer Decisions in Choosing a Sharia Bank with Religiosity as a Moderating Variable (Case Study on Customers of PT Bank Syariah Mandiri Simalungun Trade Support Branch)
}

\author{
Perkasa Al Khudri Ichwan, Paham Ginting ${ }^{2}$, Arlina Nurbaity Lubis ${ }^{2}$ \\ ${ }^{1}$ Postgraduate Students, Department of Management, Faculty of Economics and Business at Universitas, \\ Sumatera Utara, Indonesia \\ ${ }^{2}$ Postgraduate Lecturer, Department of Management, Faculty of Economics and Business at Universitas, \\ Sumatera Utara, Indonesia
}

Corresponding Author: Perkasa Al Khudri Ichwan

\begin{abstract}
This study aims to determine the effect of products and images on customer decisions in choosing a sharia bank with religiosity as a moderating variable. The population in this study were customers of PT Bank Syariah Mandiri Simalungun Trade Support Branch, namely customers who have accounts, funding product accounts or individual financing, not corporate customers and are not customers because they work in a company (such as a payroll account). The population is 2,400 customers. Sampling using cluster sampling. The analytical method used in this study is a descriptive method and the analysis technique used is structural equation modeling-partial least squares (SEM-PLS). The results showed a significant effect of products and images variables on customer decisions in choosing a sharia bank, while religiosity was not significant in moderating the effect of products and images on customer decisions in choosing sharia bank.
\end{abstract}

Keywords: Products, Images, Religiosity, Customer Decisions

\section{INTRODUCTION}

Banks are financial institutions that have a role as financial intermediaries between parties that collect funds and those who need funds (Taswan, 2010). In conventional banking, people place bank funds in return for fixed interest from the start and all interest-based products (Ifham, 2015). The interest-based system at this conventional bank is not yet fully able to meet the needs of all customers as consumers. This can be seen from the needs of the Muslim community, where the Islamic belief does not allow an interest system because it contains usury. Collecting or getting profit in the form of usury from a loan is haram. On the other hand, giving interest on savings is also haram.

To answer this condition, banking in Indonesia is now increasingly enlivened by the existence of sharia bank. Sharia bank is a financial institution with the main business of providing financing and other services in payment traffic and money circulation, whose operations are in accordance with the principles of Islamic sharia (Kasmir, 2012).

In 1990, the Indonesian Ulama Council formed a working group to establish an Islamic Bank in Indonesia. This is the forerunner to the birth of Islamic banking in Indonesia. In 1991, the first Islamic bank in Indonesia, namely Bank Muamalat was born as a pioneer in the establishment of Islamic banking in Indonesia. This bank was born by the Indonesian Ulema Council, the Indonesian Muslim Scholars Association (ICMI), 
Perkasa Al Khudri Ichwan et.al. Effect of products and images on customer decisions in choosing a Sharia Bank with religiosity as a moderating variable (case study on customers of PT Bank Syariah Mandiri Simalungun Trade Support Branch).

Muslim businessmen and also the government. Unfortunately at the beginning, the bank was less popular and its performance was stagnant. After the economic crisis and reforms in 1998, Bank Muamalat was able to withstand the crisis, while dozens of other conventional banks fell helplessly. This inspired the banking community, so in 1999 Bank Syariah Mandiri was established, which is a subsidiary of Bank Mandiri. In 2019, the number of sharia bank in Indonesia was 198 sharia bank consisting of 14 Islamic Commercial Banks (BUS), 20 Sharia Business Units (UUS), and 164 Sharia Rural Banks (BPRS).

The characteristics of the sharia banking system that operates on the basis of the profit sharing principle provide an alternative banking system that is mutually beneficial for the public and the bank, as well as highlighting the aspects of fairness in transactions, ethical investment, prioritizing the values of togetherness and brotherhood in production, and avoiding speculative activities in financial transactions. Profit sharing is a fund processing system in the Islamic economy, namely the sharing of business results between the owner of the capital (shahibul maal) and the manager (mudharib).

Sharia banking should always pay attention to changing customer behavior and many demands today. Consumers at this time tend to be more intelligent, choosy, more demanding, study well the products or services offered, have low loyalty, really care about prices, and seek the highest value (Kasmir, 2012)

To win over customers, sharia bank must determine a marketing strategy. The marketing strategy for Islamic banking based on the concept of the marketing mix is very interesting and is a necessity to accelerate the development of Islamic banking in Indonesia (Danupranata, 2013). According to McCharthy quoted in Kotler and Keller (2016), marketing mix is a combination of four variables, namely; product, price, promotion and place or what is known as the 4P model. The 4P marketing model has developed into a 7P model or service marketing mix which is more widely used in the service sector. Other strategies are people (HR, services), process (business activities), and physical evidence (company physical evidence).

In the midst of a competitive market, product innovation plays an important role and should be a priority strategy for sharia bank. The existing Islamic bank products tend to be static and very few. The product is still monotonous and even seems stiff, less dynamic and less varied. This is because currently Islamic banking has not optimally utilized the MUI National Sharia Council (DSN) fatwa (Agustianto, 2009). This product innovation is expected to be one of the strategies to continue increasing the growth of Islamic bank assets which in turn will help increase the market share of Islamic banking in Indonesia. It cannot be denied that there is a strong relationship between product innovation and the development of the Islamic banking market.

The research results of Abhimantra, Maulina and Agustianingsih (2013) state that factors such as knowledge, religiosity, products, reputation and services in sharia bank have a positive influence on the decision to choose to save at sharia bank, but not significant. Desiana et al. (2018) also concluded that the profit sharing ratio variable, the quality of religion, education, and the products offered had a significant positive effect on customers' decisions to use Islamic banking services. The results of the research by Hanik and Handayani (2014) say that the variables that have a significant effect on the decision to choose Islamic banking are product, price, promotion, place, social factors and personal factors.

Innovation efforts in Islamic banking products will differentiate Islamic bank products from conventional banks, so that there are no simplistic accusations that say that Islamic bank products are the same as conventional bank products and are merely a plagiarism of conventional bank products 
Perkasa Al Khudri Ichwan et.al. Effect of products and images on customer decisions in choosing a Sharia Bank with religiosity as a moderating variable (case study on customers of PT Bank Syariah Mandiri Simalungun Trade Support Branch).

that are added with labels or contracts. sharia (Agustianto, 2009).

This study aims to determine the effect of products and images on customer decisions in choosing a sharia bank with religiosity as a moderating variable.

\section{RESEARCH METHODS}

This type of research used in this research is associative research where associative research is research that aims to determine the relationship between two or more variables. With this research it will be possible to build a theory that will later be able to explain, predict and control a symptom (Sugiyono, 2015).

The population in this study were customers of PT Bank Syariah Mandiri Simalungun Trade Support Branch, namely customers who have accounts, funding product accounts or individual financing, not corporate customers and are not customers because they work in a company (such as a payroll account). The population is 2,400 customers. Sampling using cluster sampling.

The analytical method used in this study is a descriptive method and the analysis technique used is structural equation modeling-partial least squares (SEM-PLS).

\section{RESULT}

\section{General Description}

Bank Syariah Mandiri has been present in the City of Commerce since 2006. City of Commerce is one of the small cities in North Sumatra, Indonesia, to be precise in Bandar District, Simalungun Regency. It is located approximately $170 \mathrm{~km}$ from the city of Medan, the capital of North Sumatra and $40 \mathrm{~km}$ from the city of Pematang Siantar. The City of Commerce is surrounded by plantations, both plantations managed by the state and those managed by private or foreign private companies. The majority of residents in this city are Christians and Muslims, about $15 \%$ are Buddhists and Hindus. The ethnic groups that can be found here are Batak (Toba,
Simalungun), Karo, Javanese, Chinese, Malay, Acehnese and Indian descent. The community generally farms and trades, but some also work in home industries and palm oil processing factories. As the development began to spread evenly, around the city of Commerce, there were many swallow nests that were towering as well as business land that was sufficient to generate the economy in this city, the results of which were exported abroad. Banks such as BRI, Mandiri, BNI, Bank Syariah Mandiri, Bank North Sumatra, Bank Panin and Bank Mestika are participating in reviving the economy in trade.

\section{Company History}

The presence of BSM since 1999 was actually a lesson and a blessing after the 1997-1998 economic and monetary crisis. As is well known, the economic and monetary crisis since July 1997, which was followed by a multi-dimensional crisis including on the national political stage, has caused enormous negative impacts on all aspects of public life, including the business world. Under these conditions, the national banking industry, which was dominated by conventional banks, experienced an extraordinary crisis. The government finally took action by restructuring and recapitalizing some banks in Indonesia.

One of the conventional banks, PT Bank Susila Bakti (BSB) which is owned by the Employee Welfare Foundation (YKP) PT Bank Dagang Negara and PT Mahkota Prestasi were also affected by the crisis. BSB tried to get out of this situation by conducting merger efforts with several other banks and inviting foreign investors.

At the same time, the government merged four banks (Bank Dagang Negara, Bank Bumi Daya, Bank Exim, and Bapindo) into one new bank named PT Bank Mandiri (Persero) on July 31, 1999. The merger policy also placed and establish PT Bank Mandiri (Persero) Tbk. as the new majority owner of BSB. As a follow-up to the merger decision, Bank Mandiri consolidated and formed a sharia banking Development 
Perkasa Al Khudri Ichwan et.al. Effect of products and images on customer decisions in choosing a Sharia Bank with religiosity as a moderating variable (case study on customers of PT Bank Syariah Mandiri Simalungun Trade Support Branch).

Team. The formation of this team aims to develop Islamic banking services in the Bank Mandiri group of companies, in response to the enactment of Law no. 10 of 1998, which provides an opportunity for commercial banks to serve sharia transactions (dual banking system).

The sharia banking development Team views that the enactment of the Law is the right moment to convert PT Bank Susila Bakti from a conventional bank to a sharia bank. Therefore, the sharia banking Development Team immediately prepared the system and infrastructure, so that BSB's business activities changed from a conventional bank to a bank operating based on sharia principles under the name PT Bank Syariah Mandiri as stated in the Notary Deed: Sutjipto, SH, No. 23 dated 8 September 1999. The change in BSB's business activities to become a sharia commercial bank was confirmed by the Governor of Bank Indonesia through the Decree of the Governor of BI No.1/24/KEP.BI/1999, 25 October 1999. Subsequently, through the Decree of the Senior Deputy Governor of Bank Indonesia No.1/1/KEP.DGS/1999, BI approved the name change to PT Bank Syariah Mandiri. Following the legal establishment and recognition, PT Bank Syariah Mandiri officially began operations on Monday 25 Rajab 1420 H or November 1, 1999.

The vision and mission of PT Bank Syariah Mandiri are:

\section{Vision:}

a. Leading sharia bank: to be a sharia bank that always excels among the sharia banking industry players in Indonesia in the consumer, micro, SME, commercial, and corporate segments. b. Modern Islamic Bank: to be a sharia bank with the latest technology and service systems that exceeds customer expectations.

\section{Missions:}

a. Realizing sustainable growth and profit above the industry average.

b. Improve the quality of technology-based products and services that exceed customer expectations.

c. Prioritizing low-cost fundraising and channeling financing to the retail segment.

d. Developing business based on universal sharia values.

e. Develop talent management and a healthy work environment.

f. Increase awareness of society and the environment

PT Bank Syariah Mandiri is here, appears and grows as a bank capable of combining business idealism with spiritual values, which underlie its operational activities. This harmony between business idealism and spiritual values is one of the advantages of Bank Syariah Mandiri in its work in Indonesian banking. BSM is here to jointly build Indonesia towards a better Indonesia.

\section{Hypothesis Test}

To test the hypothesis in this study the t-statistic value was used, so for $\alpha=5 \%$ the t-statistic value used was 1.96. So that the criteria for acceptance or rejection of the hypothesis are $\mathrm{H}_{\mathrm{a}}$ accepted and $\mathrm{H}_{0}$ rejected when the t-statistic $>1.96$. Hypothesis testing is done by looking at the output path coefficient from the results of boostrap resampling as follows:

Table 1. Path Coefficient Value and P-Values (Testing the Significance of Direct Effect)

\begin{tabular}{|l|l|l|l|l|l|}
\hline & $\begin{array}{l}\text { Original } \\
\text { Sample (O) }\end{array}$ & $\begin{array}{l}\text { Sample } \\
\text { Mean }(\mathbf{M})\end{array}$ & $\begin{array}{l}\text { Standard Deviation } \\
(\text { STDEV) }\end{array}$ & $\begin{array}{l}\text { T Statistics } \\
(\mid \mathbf{O} / \text { STDEV })\end{array}$ & P Values \\
\hline Products $\left(\mathbf{X}_{\mathbf{1}}\right)$-> Customer Decisions $(\mathbf{Y})$ & 0.516 & 0.494 & 0.127 & 4.074 & 0.000 \\
\hline Images $\left(\mathbf{X}_{\mathbf{2}}\right)$-> Customer Decisions $(\mathbf{Y})$ & 0.372 & 0.391 & 0.124 & 2.997 & 0.003 \\
\hline
\end{tabular}

Based on the results in Table 1, it is obtained that the products has a positive effect on customer decisions with a path coefficient value of 0.516 (original sample column) and significant with a p-values value of $0.000<0.05$. So it can be concluded that $\mathrm{H}_{\mathrm{a}}$ is acceptable. 
Perkasa Al Khudri Ichwan et.al. Effect of products and images on customer decisions in choosing a Sharia Bank with religiosity as a moderating variable (case study on customers of PT Bank Syariah Mandiri Simalungun Trade Support Branch).

Images has a positive effect on customer decisions with a path coefficient value of 0.372 (original sample column) and significant with a p-values value of $0.003<0.05$, so it can be concluded that $\mathrm{H}_{\mathrm{a}}$ is acceptable.
Furthermore, a moderation test is carried out, whether the religiosity is significant in moderating the effect of the products on the customer decisions to choose sharia bank.

Table 2. Testing of Religiosity Moderate the Effect of Products on Customer Decisions

\begin{tabular}{|l|l|l|l|l|l|}
\hline & Original Sample (O) & Sample Mean (M) & $\begin{array}{l}\text { Standard } \\
\text { Deviation (STDEV) }\end{array}$ & $\begin{array}{l}\text { T Statistics } \\
(\mathbf{O} / \mathbf{S T D E V} \mid)\end{array}$ & P Values \\
\hline $\mathbf{M}^{*} \mathbf{X}_{\mathbf{1}}$-> Customer Decisions (Y) & 0.049 & 0.080 & 0.113 & 0.437 & 0.663 \\
\hline
\end{tabular}

Based on the results of the moderation test in Table 2, the results show that religiosity is not significant in moderating the effect of products on customer decisions, with a p-values value of $0.663>0.05$.

Table 3. Testing of Religiosity Moderate the Effect of Images on Customer Decisions

\begin{tabular}{|c|c|c|c|c|c|}
\hline & Original Sample (O) & Sample Mean (M) & $\begin{array}{l}\text { Standard } \\
\text { Deviation (STDEV) }\end{array}$ & $\begin{array}{l}\text { T Statistics } \\
(\mid \text { O/STDEV|) }\end{array}$ & P Values \\
\hline$M * \mathbf{X}_{2}$-> Customer Decisions (Y) & -0.007 & 0.015 & 0.146 & 0.049 & 0.961 \\
\hline
\end{tabular}

Based on the results of the moderation test in Table 3, the results show that religiosity is not significant in moderating the effect of images on customer decisions, with a p-values value of $0.961>0.05$.

From the results of the moderation test, it can be seen that religiosity is not significant in moderating the effect of images on customer decisions to choose sharia bank.

\section{CONCLUSION AND SUGGESTION Conclusion}

The results showed a significant effect of products and images variables on customer decisions in choosing a sharia bank, while religiosity was not significant in moderating the effect of products and images on customer decisions in choosing sharia bank.

\section{Suggestion}

Based on the research results and research conclusions, the suggestions that the authors convey are:

1. For Sharia Bank

a. Religiosity is not significant in moderating the influence of products on customer decisions. This means that the customer's decision in choosing a sharia bank is due to seeing that the product attributes of the sharia bank are solely in accordance with their financial needs, by disregarding their sharia features. In order for sharia bank to show more of their existence and differences from conventional banks, Islamic banking is expected to be more massive in instilling Islamic principles in its marketing activities. This study produces data that people are interested or interested in sharia bank because of product factors, religiosity factors play a role but are not significant. This means that the customer's motivation to avoid usury does not have a significant effect on the customer's decision to choose sharia bank.

b. In the face of developments and competition in the field of banking technology, sharia bank are expected to further modernize their products, especially in features related to technological developments such as internet banking and mobile banking because these features are in great demand by the public. And it is also hoped that sharia bank will add more modern features such as pay by barcode, cashless money, and others to be able to compete with other fintech companies.

c. Religiosity is not significant in moderating the influence of corporate 
Perkasa Al Khudri Ichwan et.al. Effect of products and images on customer decisions in choosing a Sharia Bank with religiosity as a moderating variable (case study on customers of PT Bank Syariah Mandiri Simalungun Trade Support Branch).

image on customer decisions. This means that the customer's decision in choosing an Islamic bank is due to seeing that the Islamic bank is a large and reliable bank and can meet their financial needs, not because it considers the sharia side. In order for the company's image, especially those related to the aspects of sharia, to attract potential customers to become customers of sharia banks, sharia banking is expected to improve the competence and capabilities of employees in accordance with sharia principles to support reputation in order to maintain the image of a sharia bank company.

\section{For Academics}

This research is expected to be an additional reference regarding customer decisions in using Islamic banking products.

a. For future researchers, it is hoped that this research will be developed again. It is also expected to examine other sharia bank in different areas to determine the factors that can influence customer decisions in choosing sharia bank.

b. Further researchers are also expected to expand the research and look for other factors that influence customer decisions to use Islamic banking, by adding latent construct variables, such as technology and location. Given that the independent variables in this study are only able to explain the dependent variable by $59.7 \%$.

\section{REFERENCES}

1. Abhimantara, A,.Maulina. A. R., \& Agustianingsih. E. (2013). Analisis Faktor-
Faktor Yang Mempengaruhi Nasabah (Mahasiswa) dalam Memilih Menabung pada Bank Syariah. Jurnal Proceding PESAT (Psikologi, Ekonomi, Sastra, Arsitektur \& Teknik Sipil) Vol. 5 170-177.

2. Agustianto. (2009). Pentingnya Inovasi Produk Bank Syariah. http://www.islamicfinance.co.id/berita_detai 1.

3. Danupranata, Gita. (2013). Buku Ajar Manajemen Perbankan Syariah. Jakarta: Salemba. Empat.

4. Desiana, Dewi Susilowati, \& Negina Kencono Putri. Faktor-Faktor Yang Mempengaruhi Keputusan Nasabah Untuk Menggunakan Jasa Perbankan Syariah Di Kota Tasikmalaya Volume 11 P-ISSN: 1979-858X; E-ISSN: 2461-1190, Universitas Jenderal Soedirman.

5. Hanik, S. U., \& Handayani, J. (2014). Keputusan Nasabah dalam Memilih Perbankan Syariah. Jurnal Akuntansi dan Perbankan Indonesia, 22 No.2(2), 188-202.

6. Ifham, Ahmad Sholihin. (2015). Ini Lho Bank Syariah!. Gramedia Pustaka Utama.

7. Kasmir. (2012). Manajemen Perbankan. Jakarta: Rajawali Pers.

8. Kotler, Philip \& Keller, Kevin Lane. (2016). Manajemen Pemasaran. Jakarta: Erlangga.

9. Sugiyono. (2015). Metode Penelitian Kuantitatif Kualitatif dan R\&D. Bandung: Alfabeta.

10. Taswan. (2010). Manajemen Perbankan: Konsep, Teknik \& Aplikasi. Yogyakarta: UPP STIM YKPN.

How to cite this article: Perkasa Al Khudri Ichwan, Ginting P, Lubis AN. Effect of products and images on customer decisions in choosing a Sharia Bank with religiosity as a moderating variable (case study on customers of PT Bank Syariah Mandiri Simalungun Trade Support Branch). International Journal of Research and Review. 2021; 8(2): 68-73. 